\title{
The Effect of Local Herbs on Children Oral Health Condition in Omisanjana Ado Ekiti, Ekiti State, Nigeria
}

\author{
Okunade RA* \\ Department of Dental Health, Ekiti State College of Health Sciences and Technology, Nigeria
}

\begin{abstract}
Local herbs contain antibiotic and anti-inflammatory constituents for treatment of certain diseases. The use of local herbs is dated back to many decades most especially in African countries. The 10 different oral conditions (toothache/decay, gingivitis, ulcerative gingivitis, angular stomatitis, mouth ulcers, swollen tonsil, oral thrush, tonsillitis, and black tongue) treatable with plants in traditional health practice documented in the literature were also noted in this study except for black tongue. The objective of this study is to investigate the effect of local herbs on children's oral health in Ado Ekiti. Fifty questionnaires were randomly distributed among parents in the study area. Data were collected and analyzed in percentage and graphical representations. It was concluded that local herbs has varied effects on oral health of children in the study area. It was therefore recommended that Health Educationist should enlighten the producer of local herb to scientifically demonstrate the real effects of natural medicine, as well as clarify and establish their possible therapeutic applications while parents should discourage the use of prescribed drugs in form of local herbs.
\end{abstract}

Keywords: Herbs, Oral Health, Gingivitis, Dental Caries

\section{Introduction}

Local herbs are used for treatment of some certain diseases and they come in different formulations such as leaves, flowers, stems, roots, seeds, and berries. It can be used in from of pills or powders, dissolved into tinctures or syrups, or brewed in teas and decoctions. ${ }^{1}$ Many children battle dental health problems due to the use of medicinal plants which causes toothache, pulp necrosis, brownish teeth and mummification of the pulp tissue..$^{1-3}$ However, these dental health conditions are temporary because further dental caries leads to reinfection of dental pulp tissues and consequent reoccurrence of pain. The 10 different oral conditions (toothache/ decay, gingivitis, ulcerative gingivitis, angular stomatitis, mouth ulcers, swollen tonsil, oral thrush, tonsillitis, and black tongue) treatable with plants in traditional health practice documented in the literature were also noted in this study except for black tongue. However, other additional uses like oral syphilis, oral cancer, tooth bleaching, halitosis, and dental extraction reported in this study re flect the comprehensive and nationwide spread of the study. These local herbs are also used in the treatment of diseases and food pres ervation which includes Canarium schweinfurthii, Vernonia amygdalina, Anacardium occidentale, Cocos nucifera, Allium sativum, Citrus sinensis, Carica papaya, Allium cepa, Ricinodendronheudelotii, Mangifera indica, Zea maize, and Syzygium aromaticum. ${ }^{4}$ This is in line with other studies carried out by Miller LG and Little JW who found out that some of these plants and their parts such as roots, rhizomes, tubers, leaves, stem, wood, bark, flowers, seeds, and fruits are used in various purposes in their daily life. ${ }^{5,6}$

\section{Effect of local herb on children oral health}

Study has shown that local herbs possess both positive and negative effects on children's oral health. In fact, some children have been exposed to local herbs right from their mothers' wombs due to certain herbs taken by mothers during pregnancy as remedy to some health conditions (Tables $1-3) .^{7}$
Quick Response Code:

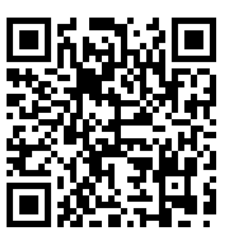

*Corresponding author: Okunade RA, Department of Dental Health, Ekiti State College of Health Sciences and Technology, Ijero, Nigeria

Received: 06 January, 2021

Published: 03 February, 2021

Citation: Okunade RA. The Effect of Local Herbs on Children Oral Health Condition in Omisanjana Ado Ekiti, Ekiti State, Nigeria. Trends Nur Health Care Res. 2021;1(1):1-4. DOI: 10.53902/TNHCR.2021.01.000502 
Table 1: Some local herb, uses and method of administration.

\begin{tabular}{|c|c|c|c|c|}
\hline Scientific names & Parts used & Forms of preparation & Diseases treated & Method of administration \\
\hline Acalypha sp & Leaves & Boil & Toothache & Gargling \\
\hline Coleus blumei & Leaves & Paste & Sore mouth and toothache & Brushing \\
\hline Sidarhombofrica & Whole & Chewing stick and mouth rinse & Toothache & Gargling/brushing \\
\hline Chenopodium ambrosioides & Whole & Paste & Toothache & Placing on painful tooth \\
\hline Masung & Seeds & Seeds & $\begin{array}{c}\text { Directing the smoke from melted paste } \\
\text { into the mouth }\end{array}$ \\
\hline
\end{tabular}

Table 2: Some local herb for specific oral diseases, explain below.

\begin{tabular}{|c|c|c|c|c|c|}
\hline Common names & Scientific names & Parts used & Forms of preparation & Disease treated & Method of administration \\
\hline Bush pepper & Ocimumbasilicum & Leaves & Deconction & Sinusitis & Sniff hot vapour \\
\hline Orange fruits & Piper guineense & Fruits & Paste in water & Dental caries & $\begin{array}{c}\text { Mouth rinse and direct } \\
\text { application }\end{array}$ \\
\hline Alakata pepper & Aframomumdanielli & Seed & Paste & Sore mouth & Gargling \\
\hline Aloe vera & Aloe vera & Leaves & Gel & Gingivitis & Rubbing \\
\hline "Native iodine & Arnica montana & Leaves & Solution & $\begin{array}{c}\text { Toothache/fresh } \\
\text { wound from extraction }\end{array}$ & Rubbing (maceration) \\
\hline Ageratum (king plant) & Ageratum conyzoides & Whole & Powder & Toothache/extraction & Brushing/direct application \\
\hline Cotton tree & Gossypium arboreum & Leaves & Hot mouth rinse & Tooth extraction & Gaggling \\
\hline Bang-api & $\begin{array}{c}\text { Dichrocephala integ- } \\
\text { rifolia }\end{array}$ & Whole & Paste & Migraine/toothache & Massaging/tooth \\
\hline
\end{tabular}

Table 3: The minerals used as adjunct were calcium carbonate, alum, bicarbonate solution, and white and yellow Sulphur.

\begin{tabular}{|c|c|c|c|}
\hline Minerals & Form of preparation & Diseases treated & Method of administration \\
\hline White sulphur & Paste & Toothache & Direct application \\
\hline Yellow sulphur & Paste & Toothache & Direct application application \\
\hline Calcium carbonate & Paste & Toothache & $\begin{array}{c}\text { Direct application in aqueous solution as mouth } \\
\text { rinse }\end{array}$ \\
\hline Alum Grounded & powder & $\begin{array}{c}\text { Bleeding gums and arrest of postextraction } \\
\text { bleeding }\end{array}$ & \begin{tabular}{c} 
Direct \\
\hline
\end{tabular}
\end{tabular}

\section{Negative effect of local herb in children oral health}

Studies have shown that children develop infections, seizures and convulsions from herbal drugs and local herbs. ${ }^{8-11}$ It's tolling effect on their dental health is alarming. Since the mouth is the gateway to the body and other essential organs, it is only noteworthy that children may respond to infections due to their small body weight and immature gastrointestinal, nervous, and immune systems. ${ }^{12-17}$ The use of some local herb can give permanent teeth a yellowish or brownish colour. ${ }^{18-20}$

\section{Possible effects}

- Excessive amounts of local herb containing fluoride can cause white or discoloured spots to form on developing permanent teeth. This is called fluorosis. Young children who routinely take fluoridated medicinal herb are at increased risk. $^{10}$

- Many local herbs reduce the flow of saliva and cause a condition called 'dry mouth syndrome'. Dry mouth significantly increases the risk of tooth decay and Halitosis.

- There can be interactions between local herb and drugs which are prescribed for children.

\section{Objectives}

1. To find out the effects of local herbs on the oral health of children in Ado Ekiti

2. To know whether local herbs are used for disease treatment in the study area.

\section{Methodology}

The researcher made use of descriptive design method with fifty of our respondents selected for this study using simple random sampling technique. The research instrument used for data collection includes questionnaire, personal interview and observation. The fifty copies of questionnaire were randomly distributed to the parents living at Omisanjana, Ado Ekiti, Ekiti State. The statistical tools utilized were simple percentage and frequency distribution.

\section{Result}

Background information about the respondents (Tables 4-8).

\section{Discussion of findings}

Table 4 showed that 19 respondents representing 38\% are of age 18-25years, 21 respondents representing $42 \%$ are of age 26-35years and 10 respondents representing $20 \%$ are of age 36 
years and above. Table 5 showed that 34 respondents representing $68 \%$ are female while 16 respondents representing $32 \%$ are male.

Table 4: Age of the Respondents.

\begin{tabular}{|c|c|c|}
\hline Age & Frequency & Percentage \\
\hline $18-25$ & 19 & $38 \%$ \\
\hline $26-35$ & 21 & $42 \%$ \\
\hline 35 and above & 10 & $20 \%$ \\
\hline Total & 50 & $100 \%$ \\
\hline
\end{tabular}

Table 5: Sex of the respondents.

\begin{tabular}{|c|c|c|}
\hline Sex & Frequency & Percentage \\
\hline Female & 34 & $68 \%$ \\
\hline Male & 16 & $32 \%$ \\
\hline Total & 50 & $100 \%$ \\
\hline Total & 50 & $100 \%$ \\
\hline
\end{tabular}

Table 6: Religion of the respondents.

\begin{tabular}{|c|c|c|}
\hline Religious & Frequency & Percentage \\
\hline Christianity & 38 & $76 \%$ \\
\hline Islam & 12 & $24 \%$ \\
\hline Traditional & None & \\
\hline Total & 50 & $100 \%$ \\
\hline
\end{tabular}

Table 7: Attitudes, Knowledge and Awareness of the children Towards Taking of local herb and Role of Health Educationists.

\begin{tabular}{|c|c|c|c|}
\hline Opinion & Response & Frequency & Percentage \\
\hline \multirow{2}{*}{$\begin{array}{c}\text { Have you ever take } \\
\text { local herb before }\end{array}$} & Yes & 39 & $78 \%$ \\
\cline { 2 - 4 } & No & 11 & $22 \%$ \\
\hline Total & & 50 & $100 \%$ \\
\hline
\end{tabular}

\begin{tabular}{|c|c|c|c|}
\hline Opinion & Response & Frequency & Percentage \\
\hline \multirow{3}{*}{$\begin{array}{c}\text { If yes, How often } \\
\text { do you take it }\end{array}$} & Once in a month & None & \\
\cline { 2 - 4 } & Twice a month & None & \\
\cline { 2 - 4 } & Once in 6 month & 7 & $14 \%$ \\
\cline { 2 - 4 } & Once a year & 43 & $86 \%$ \\
\hline Total & & 50 & $100 \%$ \\
\hline
\end{tabular}

\begin{tabular}{|c|c|c|c|}
\hline Opinion & Response & Frequency & Percentage \\
\hline \multirow{2}{*}{$\begin{array}{c}\text { Have you ever use local } \\
\text { herb for oral problem }\end{array}$} & Yes & 13 & $26 \%$ \\
\cline { 2 - 4 } & No & 37 & $74 \%$ \\
\hline Total & & 50 & $100 \%$ \\
\hline
\end{tabular}

\begin{tabular}{|c|c|c|c|}
\hline Opinion & Response & Frequency & Percentage \\
\hline \multirow{2}{*}{$\begin{array}{c}\text { How does the local herb } \\
\text { affect the body }\end{array}$} & Positive & 22 & $44 \%$ \\
\cline { 2 - 4 } & Negative & 28 & $56 \%$ \\
\hline Total & & 50 & $100 \%$ \\
\hline
\end{tabular}

\begin{tabular}{|c|c|c|c|}
\hline Opinion & Response & Frequency & Percentage \\
\hline \multirow{2}{*}{$\begin{array}{c}\text { Does the local herb } \\
\text { works for the cure }\end{array}$} & Yes & 17 & $34 \%$ \\
\cline { 2 - 4 } & No & 33 & $66 \%$ \\
\hline Total & & 50 & $100 \%$ \\
\hline
\end{tabular}

\begin{tabular}{|c|c|c|c|}
\hline Opinion & Response & Frequency & Percentage \\
\hline \multirow{2}{*}{$\begin{array}{l}\text { Have you been enlighten } \\
\text { by health educationalist } \\
\text { about local herb }\end{array}$} & Yes & 45 & $90 \%$ \\
\hline & No & 5 & $10 \%$ \\
\hline \multicolumn{2}{|l|}{ Total } & 50 & $100 \%$ \\
\hline Opinion & Response & Frequency & Percentage \\
\hline \multirow{4}{*}{$\begin{array}{l}\text { If yes, By what } \\
\text { means }\end{array}$} & Radio & 9 & $18 \%$ \\
\hline & Internet & 34 & $68 \%$ \\
\hline & Television & 7 & $12 \%$ \\
\hline & None & None & \\
\hline Total & & 50 & $100 \%$ \\
\hline
\end{tabular}

\begin{tabular}{|c|c|c|c|}
\hline Opinion & Response & Frequency & Percentage \\
\hline \multirow{2}{*}{$\begin{array}{c}\text { Do you visit the dental } \\
\text { clinic for oral care }\end{array}$} & Yes & 37 & $74 \%$ \\
\cline { 2 - 4 } & No & 13 & $26 \%$ \\
\hline Total & & 50 & $100 \%$ \\
\hline
\end{tabular}

\begin{tabular}{|c|c|c|c|}
\hline Opinion & Response & Frequency & Percentage \\
\hline \multirow{3}{*}{$\begin{array}{c}\text { How often do } \\
\text { you visit the } \\
\text { dental clinic }\end{array}$} & Once in a month & None & \\
\cline { 2 - 4 } & Twice in a month & 5 & $10 \%$ \\
\cline { 2 - 4 } & Once in a year & 9 & $18 \%$ \\
\hline \multirow{2}{*}{ Total } & None & 36 & $72 \%$ \\
\hline
\end{tabular}

Attitudes, knowledge and awareness of the children towards taking of local herb and role of health educationists (Table 7)

It was revealed that 39 respondents representing $78 \%$ have heard about local herb before while 11 respondents representing $22 \%$ are not aware what local herb is. It was also gathered that 8 respondents representing $16 \%$ take herb at least every 6 month while 42 respondent representing $84 \%$ take herb at least once in a year. $26 \%$ have used local herb for oral problem while 37 respondents representing $74 \%$ did not use local herb for oral problem. $44 \%$ said local herb have positive effect on their body while 28 respondents representing $56 \%$ said it is a negative effect on their body. It was gathered that 17 respondents representing 34\% said the local herb works for what it was used for while 33 respondents representing $66 \%$ said it doesn't work for what it was used for. 45 respondents representing $90 \%$ said they have enlightened by a health educationist about local herb while 5 respondents representing 10\%, said they haven't been enlightening by a health educationist. 37 respondents representing $74 \%$ have visited the dental clinic for oral care while 13 respondents representing 26\% did not visit the dental clinic before. 5 respondents representing $10 \%$ do visit the clinic twice a year, 9 respondents representing 18\% do visit the clinic once in a year, 36 respondents representing $72 \%$ never visit the dental clinic.

\section{Problems relating to Local herb usage (Table 8)}

39 respondents representing $78 \%$ have seen a friend with stain in the teeth while 11 respondents representing $22 \%$ haven't see a friend with stain in the teeth.14 respondents representing $28 \%$ have seen a oral problem cure by local herb while 36 respondents 
representing $72 \%$ haven't see any oral problem cure by local herb. $76 \%$ said there is a local herb that can cure for Tooth pain, $4 \%$ said there is a cure for mouth odor and $20 \%$ said there is a cure for tooth Decay. $84 \%$ said they will advice their Friends to visit the clinic for treatment of tooth pain, $10 \%$ said they will advice their Friends to use self Medication, 6\% said they will advise their friends to use local herb.

Table 8: Problems relating to Local herb usage.

\begin{tabular}{|c|c|c|c|}
\hline Opinion & Response & Frequency & Percentage \\
\hline \multirow{2}{*}{$\begin{array}{c}\text { Have you ever see friends } \\
\text { who has stain in the teeth }\end{array}$} & Yes & 39 & $78 \%$ \\
\cline { 2 - 4 } & No & 11 & $22 \%$ \\
\hline Total & & 50 & $100 \%$ \\
\hline
\end{tabular}

\begin{tabular}{|c|c|c|c|}
\hline Opinion & Response & Frequency & Percentage \\
\hline \multirow{2}{*}{$\begin{array}{c}\text { Have you see any dental } \\
\text { problem cure by local herb }\end{array}$} & Yes & 14 & $28 \%$ \\
\cline { 2 - 4 } & No & 36 & $72 \%$ \\
\hline Total & & 50 & $100 \%$ \\
\hline
\end{tabular}

\begin{tabular}{|c|c|c|c|}
\hline Opinion & Response & Frequency & Percentage \\
\hline \multirow{2}{*}{$\begin{array}{c}\text { Local herb can be use } \\
\text { to cure }\end{array}$} & Tooth pain & 38 & $76 \%$ \\
\cline { 2 - 4 } & Mouth odour & 2 & $4 \%$ \\
\cline { 2 - 4 } & Teeth decay & 10 & $20 \%$ \\
\hline Total & & 50 & $100 \%$ \\
\hline
\end{tabular}

\begin{tabular}{|c|c|c|c|}
\hline Opinion & Response & Frequency & Percentage \\
\hline $\begin{array}{c}\text { With the level of civiliza- } \\
\text { tion, What advise will you } \\
\text { give a friend or someone } \\
\text { who experience tooth } \\
\text { pain. }\end{array}$ & Visit the clinic & 42 & $84 \%$ \\
\cline { 2 - 4 } & Self medication & 5 & $10 \%$ \\
\hline Total & Use of local & 3 & $6 \%$ \\
\hline
\end{tabular}

\section{Conclusion}

It was therefore concluded that local herbs has varied effect on oral health of children in the study area. There are evidence of usage of herbal medicines of different formulations as confirmed by respondents while some believed herbal medicine has no negative effect on oral health of children, majority believed dental health problems such as brownish teeth, gingivitis etc are due to uncontrolled use of local herbs.

\section{Recommendations}

a. Parents should not equate "natural" with "safe."

b. Parents should seek expert guidance on the use of local herbs if need be.

c. Parent should discourage self-medication due to toxicity of certain plants.

d. Unlike drugs, herbal products have not been scrutinized by NAFDAC, so it is truly a case of "buyer-beware." Hence, public awareness should be given to prevent the base of herbal medicine.

e. Government should deploy Health Educationist to ensure home visitation in enlighten children and parents on the usage of local herb for oral care f. Government should regulate producer of local herb to scientifically demonstrate the real effects of natural medicine, as well as clarify and establish their possible therapeutic applications.

g. Local herbs should be analyzed to evaluate their effectiveness as possible pharmaceutical sources and/or support their use for oral care as treatments.

\section{Acknowledgments}

None.

\section{Conflicts of interest}

There is no conflict of interest to declare.

\section{Funding}

The researcher received no funding for this work.

\section{References}

1. Anushri M, Yasoda R, Puranik MP. Herbs: A good alternative to current treatment of oral health. 2015

2. Sinha DJ, Sinha AA. Natural medicaments in dentistry. Ayu. 2014;35(2):113-118.

3. Sinha A, Bhardwaj SV. Role of medicinal herb in prevention and treatment of dental disease. AAM. 2012;1(3):95-101.

4. Ríos JL, Recio MC. Medicinal plants and antimicrobial activity. $J$ Ethnopharmacol. 2005;100(1-2):80-4.

5. Miller LG. Herbal medicinals: selected clinical considerations focusing on known or potential drug- herb interactions. Arch Intern Med. 1998;158(20):2200- 11.

6. Little JW. Complementary and alternative medicine: Impact on dentistry, oral surgery, oral medicine, oral pathology. Oral Surgery Oral Medicine Oral Pathology and Oral Radiology. 2004; 98(2):137-145.

7. Bisset NG. Herbal drugs and phytopharmaceutical. 1994.

8. D'Auria FD, Tecca M, Scazzocchio F, et al. Effect of propolis on virulence factors of Candida albicans. J Chemother. 2003;15(5):454-60.

9. Jain N, Rajwar YC Batra M, et al. Dentistry turning toward Herbal alternatives. 2014.

10. Rakesh Oswal SC. Herbal therapy in dentistry. Innovative Journal of Medical and Health Science. 2011;1(1).

11. Ntie-Kang F, Lifongo LL, Mbaze LM, et al. Cameroonian medicinal plants: a bioactivity versus ethnobotanical survey and chemotaxonomic classification. BMC Complement Altern Med. 2013;13:147.

12. Dibong SD, Mpondompondo E, Ngoye A. Inventory and biodiversity of species edible wild fruits sold in the market of douala, Cameroon. 2011.

13. Din N, Mpondompondo E, Dibong SD, et al. Inventory and identification of plants used in treatment of diabetes in doualatown (Cameroon). 2011;1(3):60-73.

14. Fatovich DM. Aconite: a lethal Chinese herb. Ann Emerg Med. 1992;21(3):309-311.

15. Toxic reactions to plant products sold in health food stores. Med Lett Drugs Ther. 1979;21(7):29-32.

16. Benner MH, Lee HJ. Anaphylactic reaction to chamomile tea. J Allergy Clin Immunol. 1973;52(5):307-308.

17. Roulet M, Laurini R, Rivier L, et al. Hepatic veno- occlusive disease in newborn infant of a woman drinking herbal tea. $J$ Pediatr. 1988;112(3):433-436.

18. Pages N, Salazar M, Chamorro G, et al. Teratological evaluation of Plectranthusfruticosus leaf essential oil. Planta Med. 1988;54(4):296-298.

19. Eisenberg DM. Advising patients who seek alternative medical therapies. Ann Intern Med. 1997;127(1):61-69.

20. Ang- Lee MK, Moss J, Yuan CS. Herbal medicines and perioperative care. JAMA. 2001;286(2):208-216. 